\title{
IMPROVING HUMAN RESOURCES REPORTING IN NON FOR PROFIT ORGANIZATIONS
}

\author{
Nicolae Todeal \\ Delia Corina Mihălțan ${ }^{2}$
}

\begin{abstract}
The paper aimes to expose the present reality concerning the information offered by accounting regarding the human resources in a non for profit organization and to propose ways of improving it. To this end we display the typical aspects of human resources which are connected to the specificities of the non for profit organizations and their impact on accounting. We emphasize the deficiencies of human resources reporting and submit means of improving it.
\end{abstract}

Keywords: non for profit organization, employees, volunteers, expenditures

JEL Codes: $M 40$

\section{Introduction}

Non-guvernamental organizations have an important role in society whereas through their activity they answer to the citizens needs in the social, cultural, educational and health plan, supporting thereby, in a smaller or greater degree, the authorities in organising and managing the comunity they serve. In Romania this type of entities can be constituted as associations, foundations, federations operating on the basis of specific laws set for them.

Considering the present socio-economic context the number of non for profit organizations in Romania has increased and implicitly the number of the persons who are involved in their activity or are working for them. This is the reason for which we focus on the human resources role and their typical aspects in the non for profit organizations.

In a knowledge economy, the human resource represents the most important and valuable resource used in the work process in any type of entity. Human resources represent the means by which all the other resources are harnessed and used, therefore many times the sucess of an organization depends on the way that human resorces achieve the strategic objectives set by the organization. This is another reason that rised the interest on the chosen subject.

Similarly to the other entities, the nonprofit organizations have to deal with various users of the financial-accounting information. Which is why the present paper work aim to analyze the disclosure regarding the human resources manifested by the nonprofit organizations. In order to reach this goal, we have proposed some objectives. Firstly is understanding the actual relationship between the organization and human resources, their role and types. Secondly is observing the existent methods related to the evaluation and presentation of some information concerning the human resources. The next objectiv is to see, beyond the theory, the applicability of the legal requirements regarding the disclosure of human resources. Finally we will draw down the conclusions and present the proposals issued by the comparison between the theoretical situation and the practical one.

\footnotetext{
${ }^{1}$ „1 Decembrie 1918” University of Alba Iulia, Romania, e-mail: ntodea@uab.ro

2"Valahia” University of Târgovişte, Romania, e-mail: dellya_c@yahoo.com
} 


\section{Research methodology}

As we have mentioned above, the main objectiv of the paper is to expose the present reality regarding the use of the human resources in a non for profit organisation and whether its image presented by accounting is an accurate one.

We will present the specific aspects of human resources in a non for profit organization and what are the accounting implications of using human resources. By studying the present state of this field (the literature, the regulation in force and the practice) we aim to emphasize ways of improving the accounting reporting regarding the human resources in a non for profit organization. Thus the paper's hypothese is that accounting offers accurate informations regarding the human resources in a non for profit organization.

In order to achive the set objectives and for presenting proposals we review the literature in this area, we study the financial statements of a non for profit organization and critically analyse the law in force related to the role of human resources accounting.

\section{Literature and law review}

Generaly speaking an organization represents a body of people founded for a common purpose. The existence of any organization is based on the interactions between individuals pursuing the same objective. The fundamental reasons for the appearance and development of organizations are the limited feature of physical and intelectual human capacities and the fact that people are social beings. The building of an organization is based on the hypothesis that the general objectives are known, accepted and followed by all members and personal objectives are conformed to the general objectives of the organization. (Stan, Anghel, Gruzsniczki, 2006)

The term "non for profit organization" is generally used to refer to those entities that are not aimed to make a profit. The Fiscal Code defines the non for profit organization as "any association, foundation or federation founded in Romania in accordance with the law in force, only if their income and assets are used for a general, communitarian or non-patrimonial interest."

The literature (Deaconu, 2010, Diaconu, Pitulice, 2007, Tiron-Tudor, Muțiu, 2000) defines this entities according to the law in force. The organizations, in legal terms, in Romania take the form of associations and foundations as defined in Law no. 246/2005 approving Government Ordinance no. 26/2000 on associations and foundations:

- The association is the legal entity formed by three or more persons who, according to an agreement, are pooling and not subject to refund material contribution, knowledge or contribution in labor with the purpose of carrying out activities in the general interest of some communities or, where appropriate, in their private prerogatives.

- The foundation is the legal entity established by one or more persons on the basis of a legal act between the living or upon death and constitutes a patrimony permanently and irrevocably affected to achieve a goal of general interest or, as the case of some communities.

- The federation is the body established by the association of two or more associations/foundations for specific purposes.

A major characteristic of these entities that has an impact on their human resources consists in their right to employ paid human resources according to a labor contract or to work with volunteers based on Volunteers contract, in both cases complying with the law in force. Hence the distinction between foundations and associations: while both can employ volunteers, their role in associations is more important than in the case of foundations. Both foundations and associations develop their activities based on a patrimony but foundations reach their objectives mainly through their patrimony, while associations can establish objectives that can be reached without a patrimony.

Regarding the paid human resources the non for profit organizations act the same way as any other employer complying with the law in force. Volunteering is the specific activity in the non for profit organizations and is regulated in Romania by the Volunteering Law no. 195/2001 
republished. This law defines volunteering, establishes the circumstances for its development and the document on which this is based: the Volunteers contract. Its structure, the terms and conditions, the rights and duties of each party are also established by the law.

This law defines volunteering as: "the public interest activity performed out of own initiative by any person on the behalf of others without expecting any material advantages. The public interest activity is developed in fields such as: social aid and support, human rights, health services, cultural, artistic, education, scientific, humanitarian, religious, sport, environmental, community and other similar to these".

A Pro-Vobis on-line publication The National Center of Volunteering Resources expresses the concern for the wrong perception regarding volunteering: "The problem is, simply stated, that volunteering is such a fashionable concept that more and more places are called volunteering without being so in fact." In our opinion this phenomenon appears as a result of misinformation concerning volunteering on the part of the organizations and the potential volunteers.

By definition the voluntary activity cannot be taken for the paid activity which is developed based on a labor contract. Nevertheless there is a risk that a volunteering contract would replace a labor contract. The risk generator factor consists in the tax liabilities of the employer (eg. The employers obligation to pay social insurance for its employees to the national insurance budget). The volunteering law is inflexible concerning this risk and makes the following assessment in the $4^{\text {th }}$ article: "It is forbidden to sign a volunteering contract in order to replace a labor contract or any other kind of contract by onerous title.

The difference between a Volunteering contract and a labor contract consists in the existence of various rights and liabilities of the parties, of which the most important refer to retribution and the compulsoriness of meeting the quota according to the Contract.

„Organizations constitute a complex human reality whose action depends on the level of employment of the ones involved. Therefore, among the resources that organizations use, human resources hold a primary place as they represent the ,soul' which gives life to the systems, having a distinct feature because they are part of the numerous social systems. This multiple and complex social affiliation offers the individual a certain set of beliefs, habits, values, professional training, certain interests and demands." (Marin, 2011)

On an international level, there is no specific framework for the accounting of the nonprofit organizations, for example the one of the IPSAS for the public sector. The introduction of the International Financial Reporting Standards is mentioning the posibility of adapting their aplicability for every entity that has another purpose than making profit. Therefore we examined the IAS 19 which reffers to reports regarding the human resources and the efforts made with these. Currently within the accounting field, are recognized as expenses of the period: the employees' benefits and the expenses with their training and their competences improvement. Disclosing this particular expenses provides to the public an accurate base for creating an opinion about the existing human resources within a nonprofit organization. Accordingly to IAS 38 these elements are not fullfiling the recognition criterias as intangible assets even though they are efforts generating future benefits. The literature (S., V., Stan, I., Anghel, V., Gruzsniczki,, 2006) based on IAS 38 is affirming the possibility of recognition as intangible assets of the labour contracts which are advantageous for the employer in the case of a contractual salary under the legal limit. The volunteering contracts which are signed for a determined period within a nonprofit organization could be considered such advantageous contracts, especially because the contractual salary is not only under limit, but is definetly lacking. Due to the fact that in Romania the accounting is not obeying the IFRS, we can only recommend the disclosure of the main information for the public regarding the volunteers within the nonprofit organization. Moreover, the entities are encouraged to present a brief description of the significant intangible assets that are controled by entity (power to obtain benefits from the asset), but which are not recognized as assets because do not meet one or more recognition criterias. 
Just like any other entities, non-profit organizations exist with a certain purpose, which is not to attain proffit, but to offer services, support, to add to the development on the social, educational, cultural, religious, political, social services and health plan. In order to attain their purpose, they need first of all human resources which could subscribe to the purpose for which the organizations have been established and which could implement and fulfil the vision of the organization by setting strategic objectives.

\section{Results and discussions}

\section{The implications of using human resources}

On a general scale, due to the vast econmical knowledge involved, the quantization of human capital in an entity represents a challenge for the researchers and managers involved in this field or in similar problems. „The intensifying of the current debates in the more detailed understanding of the place, the importance and the contribution of the intelectual capital in the growth of the value of the company to which it belongs was the direct and convincing effect of the essential changes occurring in the last two decades in the society." (S., V., Stan, I., Anghel, V., Gruzsniczki,, 2006)

As I have presented previously, any organization is built on certain interactions between individuals who follow the same objectives and thus we can observe the importance of human resources in regarding the fulfilment of the purpose for which the organization exists. For a nonprofit organization we cannot talk about the concept of market value; nobody wants to invest because the purpose of its existence is not to generate profit, in this regard we cannot state that the quantization of human capital has any relevance. However, the extent to which a juridical person who doesn't bear the patrimonial liability reaches the set objectives is influenced by the quality of the human resources that he/she has at disposal, regardless of their status - employed or volunteers. This is crucial if we consider the fact that such an entity is believed as performant not on the basis of the financial result at the end of the reporting period, but basically according to the extent to which it reaches its objectives, measure quantified especially through non-financial indicators. The level of competence could be represented through the number of occupied positions by employees which have a specific qualification in accordance with the occupied position.

The issue of evaluating the human capital becomes therefore important in the above presented context, especially so that the non-profit organization can maximize its performance fully showing its established objectives, and even so that it can extend its activity by setting new objectives. However, the human resources performance can be observed in the results of the developed projects. Also, the issue of the human capital evaluation is signaled even in the unfortunate situation in which the organization does not reach its set objectives in the case when it continues to have the necessary financial resources and/or the circumstances in which it works remain unchanged.

For a non-profit making organization, investment in human resources is therefore important and is represented in the total of expenses made for recruting, hiring, instructing or the employees and volunteers, in such a way that they can contribute to the growth of the performance.

Besides the investment in human resources, human capital has more components which we will present next in Table 1. They refer to the employees as well as to volunteers. 
Table no. 1 .

\section{Components of human capital}

\begin{tabular}{|c|c|c|}
\hline \multicolumn{3}{|c|}{ HUMAN CAPITAL } \\
\hline Proficency & Behavior & Intelectual ability \\
\hline $\begin{array}{l}\text { - Knowledge gathered through } \\
\text { education; } \\
\text { - Training/instruction; } \\
\text { - Talent; } \\
\text { - Practical experience. }\end{array}$ & $\begin{array}{l}\text { - Motivation / altruism; } \\
\text { - Communication / team } \\
\text { - work; } \\
\text { - Ethic behavior towards the } \\
\text { values of society. }\end{array}$ & $\begin{array}{l}\text { - Observation } \\
\text { assimilation of innovation } \\
\text { from other domains } \\
\text { - Self innovation; } \\
\text { - Adjustment to new work } \\
\text { conditions } \\
\text { - Ability to put into shape } \\
\text { ideas }\end{array}$ \\
\hline
\end{tabular}

Source: S., V., Stan, I., Anghel, V., Gruzsniczki, Capitalul uman al întreprinderii. Evaluarea proprietății intelectuale şi a altor active necorporale, pg.6

We can notice the incorporeality of the components of human resources, however all these get into shpate through the quality of the work done by the volunteers and employees, which has effect over the performances of the organization. In the light of this, the evaluation of the human capital becomes important, especially in the situation in which the organization wants to expand its activity. Empirically speaking on this structure of human capital it could be made a test that every employee must fill in as part of their self-evaluation program developed within the organization. The test results could be integrated and disclosed.

Nevertheless, according to the national and international norms belonging to the accounting domain, human resources do not enforce all the criteria of their acknowledgement in the balancesheet assets. Although they are important resources for any entity, they are not resources which can be controlled by it, because each person is free to choose the work place where they want to be active. The use of the work force generates significant expenses for the organization, and the components of the human capital above described are seen as expenses of one period, which will eventually affect the result. Based on this accounting information, an indicator which can be constructed is "The estimated costs of replacing the skilled human resources". To be able to calculate this indicator, it is required the existence of training programs within that organization for both employees and volunteers. This indicator estimates the current costs for creating a similar intangible asset to the evaluated one. The amount of the indicator is calculated by adding all recruiting and training expenses made with the current employees, starting with their employment date.

The information provided by accounting concerning the employees are found as of salaries costs, salaries extras, recruitment costs, training costs, and others, just as in the case of any other employer. Thus, in the financial statement we can find information about the employees in the fiscal year results account and brief and general information in Note no. 8 on the financial statement - „Information about the employees and the members of the board of administration, leadership and control", with the note that it refers to information on the labour force which is employed and payed.

Regarding the existence of voluneteers, accounting does not offer information, although volunteering can be done in any non-profit organization and is legal. If for employees it is mandatory to keep the Revisal electronic registry book, for the volunteers part the law requires that at the headquarters of the organization a registry book be kept for volunteers (hard copy). Due to the fact that volunteer work is not payed, from an accounting point of view, their existence within the organization does not generate bookkeping unless the contract specifies the right of the volunteer to have the expenses for his activity discounted. Nevertheless, through the work done by the volunteers the performances of the non-profit organization can be maximized, but because of 
their nature, performances are not measured in the difference between revenue and expenditure, but in the level to which the objectives have been met.

One specific aspect of most non-profit organizations is the existence of an employee who has the task to coordinate the volunteers, who would be responsible just to organize and train them. We could say that this would add to the expenses which compose the investment in human resources thr cost of keeping this job (salary and extras).

As a consequence to using volunteers, due to the legal requirements from this domain, the censors and auditors from non-profit organizations need to consider setting specific objectives which have to assure that these provisions are respected.

Because through accounting we present brief information regarding human resources, we consider of great importance the improvement of Note no. 8 - „Information about the employees and the members of the board of administration, leadership and control", by adapting it to the nature of non-profit organizations. Currently, The 3rd Section of OMEF 1969/2007 stipulates that Note no. 8 will have specifications regarding the following:

a) allowances given to members of the board of administration, leadership and control;

b) contractual obligations regarding the payment of retirement benefits towards the former employees of the board of administration, leadership and control, indicating the total value of commitment for each category;

c) the value of advance money and credits given to members of the board of administration, leadership and controlduring the financial year:

- interest rate;

- main terms of the credit;

- reimbursed amount up to that date;

- future obligations such as securities born by the entity in their name;

d) employees:

- average number, divided on each category;

- payed or to be payed salaries, according to the financial year;

- expenses for social insurances;

- other costs for pension contributions."

Due to the fact that we consider that the information on human resources are not controled suficiently, we propose the development of point ,d) employees" with the help of Table no. 2 below, which gives a possible structure of the information presented.

Table no. 2

Information regarding employees and volunteers

\begin{tabular}{|c|c|c|c|c|}
\hline No & Indicator name & $\begin{array}{l}\text { Non-profit } \\
\text { activity }\end{array}$ & $\begin{array}{c}\text { Economic } \\
\text { activity }\end{array}$ & $\begin{array}{l}\text { Special } \\
\text { activity }\end{array}$ \\
\hline I & EMPLOYEES & & & \\
\hline 1 & Average number of employees & & & \\
\hline 2 & Total salaries capital, out of which: & & & \\
\hline $\begin{array}{l}- \text { En } \\
- \text { In } \\
- \text { En } \\
- \text { En } \\
- \text { En } \\
-\mathrm{Co} \\
\text { (per } \\
-\mathrm{Cc} \\
-\mathrm{Cc} \\
\text { func }\end{array}$ & $\begin{array}{l}\text { ployees' salaries } \\
\text { ome tax according to the type of salaries } \\
\text { ployee's contribution to social security } \\
\text { ployee's contribution to health insurance } \\
\text { ployee's contribution to unemployment fund } \\
\text { tributions of the organization towards social security } \\
\text { sion fund, and workplace accident risk fund) } \\
\text { ntributions of the organization for health insurance } \\
\text { ntributions of the organization towards unemployment } \\
\text { and the fund that guarantees the liability of salaries }\end{array}$ & & & \\
\hline
\end{tabular}




\begin{tabular}{|c|l|l|l|l|}
\hline No & \multicolumn{1}{|c|}{ Indicator name } & $\begin{array}{c}\text { Non-profit } \\
\text { activity }\end{array}$ & $\begin{array}{c}\text { Economic } \\
\text { activity }\end{array}$ & $\begin{array}{c}\text { Special } \\
\text { activity }\end{array}$ \\
\hline 3 & Recruitment, training and development costs & & & \\
\hline 4 & Transpost, accomodation and meal costs & & & \\
\hline II & VOLUNTEERS & & & \\
\hline 1 & Average number of volunteers & & & \\
\hline 2 & Average number of hours done by a volunteer & & \\
\hline 3 & Recruitment, training and development costs & & \\
\hline 4 & Transpost, accomodation and meal costs & & \\
\hline 5 & Other costs for volunteers & & \\
\hline 6 & Estimated cost for replacing volunteers with employees & & & \\
\hline
\end{tabular}

We consider that information concerning human resouces should be presented according to the type of activity, especially because of the specific of the non-profit organizations, respectively the possibility to develop the three types of activities mentioned before. There should be information about the number of employees as well as of volunteers for each type of activity. Also, in order to provide a good transparency of the image that is presented about the human resources, besides the costs for the salaries of employees, there should be presented, if existent, other costs regarding employees and volunteers (costs for meals, accomodations, trips, training, formation and development costs). Also, other costs concerning the volunteers can include salary costs for the volunteer coordinator, a person who is employed to be in charge with and coordinate volunteers' activities.

We consider appropriate to introduce the indicator „Estimated cost for replacing volunteers with employees" as this will state numerically the gain of the organization due to using volunteers. For this indicator, we propose the following formula for calculation:

$$
\mathrm{RC}=\sum_{\mathrm{i}=1}^{\mathrm{n}}\left(\mathrm{Th}_{\mathrm{n}} \times \mathrm{S}_{\mathrm{n}}\right) \text {, where: }
$$

$\mathrm{RC}$ - minimal cost estimated for replacing volunteers with employees;

$\mathrm{Th}_{\mathrm{n}}$ - total number of hours done by the volunteer;

$\mathrm{S}_{\mathrm{n}}$ - salary per hour for the occupied position, including employee benefits owed by the organization;

$\mathrm{n}$ - position occupied by the volunteer for whom the hours and salary is being calculated.

By presenting the information comprised in Note no.8 - „Information about the employees and the members of the board of administration, leadership and control", we consider that the nonprofit organization's transparency concerning human resources, be it employees or volunteers, is improved.

\section{Conclusions and proposal}

Human resources represent a key element in a non-profit organization's existence particularly because they are constituted by human colectivities who have common purposes. Due to the fact that they do not pursue the gain of profit and are private companies, non-profit organizations can use volunteers in their activities. By commiting themselves to the objectives of the organization employees and volunteers contribute to their accomplishment, maximizing the performance of the entity. We therefore observe the way in which the caracteristics of non-profit organizations impact human resources.

Under these conditions the evaluation of human capital is an acute need, especially if the organization wants to develop its activity or if it notices that the objectives which have been set have not been met. But since human resources cannot be controled resources, they cannot be 
recognized in the balance sheet. Looking beyond the regulation in force, let us not forget that the major role of accounting is to reflect a true image of reality. We therefore dare to propose the recognition of human resources as assets in the off-balance sheet account, whether it is for employees or volunteers especially because of the issue of controling these resources. Also, it is absolutely necessary the improvement of the information presented in Note no. 8 ,Information about the employees and the members of the board of administration, leadership and control". This way reality will be better presented, because both employees and volunteers add to the value of there organizations, most of them being built legally on volunteer labour.

Currently, concerning the employees with an individual employment contract, the accounting implications are identical to those of commercial companies, generating the same type of accounting monography, concerning remuneration. Regarding the volunteers, the only thing needed is to present the legal requirements for volunteering, and the control and audit activities need to follow the rules for that particular domain, besides the other objectives normally followed concerning human resources.

Knowing that a non-profit organization is considered performant according to the level to which it meets its objectives (this level being influenced by the quality of human resources) one direction towards the indepth research of this subject would be the quantification or the performance of a non-profit organization.

\section{References}

1. Deaconu S. C., 2010. Reglementări şi practici contabile specifice: Note de curs, Alba Iulia: Editura Universității „1 Decembria 1918”.

2. Diaconu G., Pitulice C., 2007. Contabilitatea financiară a organizațiilor non-profit, Ploieşti: Contaplus.

3. Marin I., 2011. Auditul Resurselor umane, Bucureşti: Economică.

4. Stan S. V., Anghel I., Gruzsniczki V., 2006. Capitalul uman al întreprinderii. Evaluarea proprietății intelectuale şi a altor active necorporale, Bucureşti: Iroval.

5. Tiron-Tudor A., Muțiu A., 2000, Asociații şi fundații - aspecte juridice, fiscale şi contabile, Cluj-Napoca: Dacia.

6. Todea N., 2009. Teorie contabilă şi raportare financiară , Alba Iulia: Aeternitas.

7. Mihălțan D., Corina, 2012. „Specificități ale auditului resurselor umane în cadrul organizațiilor non-profit" în revista Audit financiar, nr. 6/2012, pp. 22-28.

8. *** The Labor Code of 18 May 2011 published in Official Monitor of Romania no. 0345.

9. *** Law no. 571 of 22 December 2003 regarding the Fiscal Code, as amended and completed, republished.

10.*** Law no. 246 approving Government Ordinance no. 26/2000 on associations and foundations, published in (2005) Official Monitor of Romania no. 656.

11. *** The public audit law no.672/2002, republished in (2011) Official Monitor of Romania, Part I no. 856.

12. *** Law no. 125 regarding volunteering republished in (2007) Official Monitor of Romania no. 276.

13. *** OMEF no. 1.969/2007 regarding the non-profit organizations accounting regulations published in Official Monitor of Romania no. 864bis/2007.

14. www.voluntar.ro, 27.07.2013. 